\title{
Research on the Flip the Classroom Teaching Mode for Innovation Entrepreneurship Classes under the MOOCs Background
}

\author{
Shenghong Liu \\ Hankou University, \\ Wuhan 430212 Hubei,P.R.China
}

\begin{abstract}
In this paper, we conduct research on the flip the classroom teaching mode for the modern innovation entrepreneurship classes under the MOOCs background. Job creation and encourage the entrepreneurship to create more employment opportunities will be a long-term policy, which puts forward higher requirements on entrepreneurship education in colleges and universities, we need for the current problem restricting the development of entrepreneurship education in colleges and the universities well as in-depth research. In view of the special practical entrepreneurship education, many universities invite entrepreneurial experience for the entrepreneurship lectures, entrepreneurial guidance. It should be worth promoting, but we also want to see, entrepreneurial faculty have their weakness. Under this background, we combine the MOOCs and flip the classroom teaching mode to form the novel education paradigm which holds special meaning.
\end{abstract}

Keywords- MOOCs Background, Flip the Classroom, Innovation Entrepreneurship, Teaching.

\section{Introduction}

Entrepreneurship education is a vocational education in the new period and the important content of ideological and political education, to the survival of individual and social stability and development is of great significance. Therefore, the colleges and universities should comply to widely implement entrepreneurship education.
The fundamental problem of the higher education is the question of what talent cultivation, while the training of talents will influence the direction of the economic and social development and progress, which involves the comprehensive quality education. Entrepreneurship education is indispensable to the overall quality education as an important aspect to implement and strengthen entrepreneurship education that is of special significance to our country [1-2].

According to the literature survey, the challenges for enhancing the entrepreneurship education can be roughly summarized as the follows. (1) We need improve the talent evaluation mechanism. In the process of the construction of a modern vocational education system, to improve the basic vocational qualification certificate system and employment access system, connotation of vocational education is the real display. At the same time we also want to ensure that our country occupational qualification standards docking with the state specified standards, promote vocational education in our country to develop in international standard. (2) We need to form scientific and effective, unified coordination management body. Multi-sectoral management is likely to cause the management responsibility is not clear, low efficiency, as well as vocational education reform and development of increased resistance. In the modern vocational education system in the process of building, to make among the various levels of the vocational education can join smoothly, urgently needs to form a scientific and effective, unified coordination management system to manage the development of the 
vocational education. (3) The need to establish a perfect and clear legal security system. In the development of the vocational education system, the relevant departments should update and perfect the legal system of vocational education, so as to make the development of vocational education has been further guaranteed [3].

In recent years, large-scale online open course (MOOC) has attracted global attention, and at same time, many universities in China are also on the education actively responds to the new thing. Various universities in teaching practice, further deepening the reform of the education teaching construction and teaching reform, encourage MOOC, according to the construction of teaching team as a carrier for MOOC. Compared with exquisite course, video session, MOOC prompted students to participatory, exploratory, experiential learning. In this context, we need to think about MOOC era the requirements of teaching team in colleges and universities, and form a MOOC era in the field of interdisciplinary, cross the basic strategy of teaching team construction. MOOC era a high level, the highly effective teaching team should have the common goal, effective leadership and good communication and the common goals can inspire passion and centripetal force of teaching team, each team member will for this aim while this goal can be guidance for team members to provide power. In the figure one, we show the sample MOOC based curriculum system by MIT, Stanford and Coursera [4].

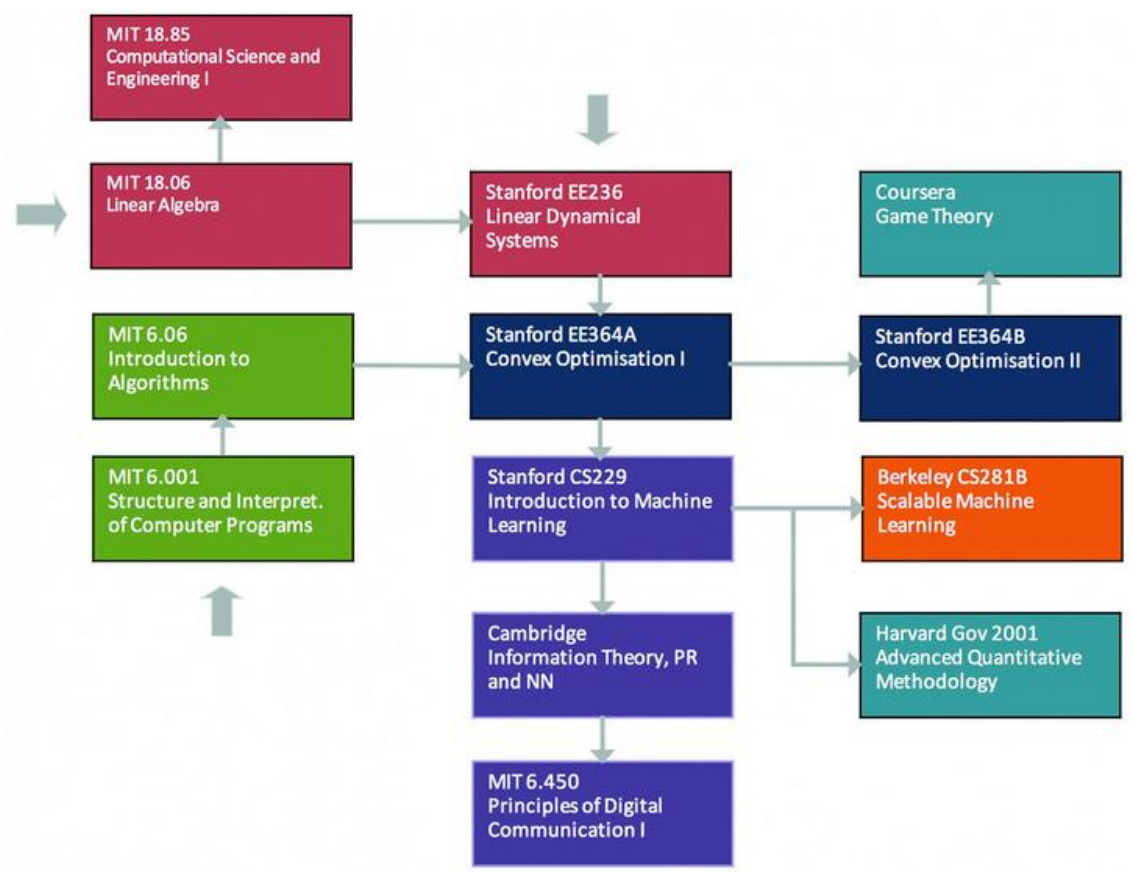

Figure 1. The Sample MOOC based Curriculum System

In this paper, we conduct research on the flip the classroom teaching mode for modern innovation entrepreneurship classes under MOOCs background. In today's employment situation is increasingly serious, college students' employment is the common problems of colleges and universities. How to improve university students' employment quality from the source, the overall improving the quality of employment, employment has become the focus for the colleges and universities today. Employment, entrepreneurship is a systematic project, to ensure smooth employment source from the cultivation of the student employment, entrepreneurship, employment guidance and the entrepreneurship education courses as the direct 
guidance of cultivating ability of student employment entrepreneurship course plays a vital role. In later parts, we will propose our methodology in detail.

\section{Our Proposed Methodology}

The Flip the Classroom Teaching Mode. Flip classroom as a teaching design method, has become the domestic and foreign scholars and education workers a hot problem in the research and practice, and its positive role to the classroom, positive influence to the teaching effect has been unanimously recognized scholars and education practitioners. Abroad, to turn the classroom is comparatively deep research, has accumulated a certain research foundation, more education practitioners beginning for students not types, different subjects, different course, the reverse applied to class teaching, after the certain time to flip classroom practice that have achieved good teaching effect. In the following list, we summarize the advantages of the flip the classroom teaching mode [5-6].

- "Flip" will be students actively explore and harmony under the guidance of teachers. "Flip" classroom upside down the traditional teaching order, also broke the traditional teaching in the teachers' classroom teaching as the main teaching way that make teaching students take the initiative to explore, to teach and to guide the learning process.

- "Flip" class is problem oriented teaching. Different from the traditional classroom teaching, classroom "flip" is a problem as the guidance, the students in a teaching environment problem for clues in exploring and solve problems, students learn to think constructing knowledge.

- "Flip" makes full use of network tools for teaching class. "Flip" classroom teaching is divided into class and class two parts, whether teaching video production to create the class teaching, students for learning or the video data communication between students and teachers are all dependent on the network platform. The use of information technology and network tools to improve the teaching efficiency, on the one hand can make a lot of learning and inquiry with the aid of network platform outside the classroom, on the other hand to make the students learn more humanized and liberalization knowledges.

The traditional teaching process usually includes knowledge and knowledge internalization in two stages. Knowledge is done through teachers teaching in the classroom, knowledge internalization requires students through practice operation, operation, or to do after class. In turn classroom teaching mode, this form was upset, knowledge through the auxiliary complete after class of the information technology, knowledge internalization is integrated by the help of teachers with the help of classmates in class and complete, and thus formed the flip the classroom.

The Principles of the Entrepreneurship. Different course content and structure have different functions, to achieve the goals of entrepreneurship education courses, needs the support of reasonable course content and structure. According to development trend of modern education and connotation and orientation of entrepreneurship education courses, entrepreneurship education curriculum should include pioneering consciousness, quality, entrepreneurial capability and entrepreneurial knowledge and so on four aspects of content, its structure shall be composed of relatively independent entity with a comprehensive curriculum and penetration in various scientific and cultural foundation courses and the professional courses and related education activities of a branch course of entities. 


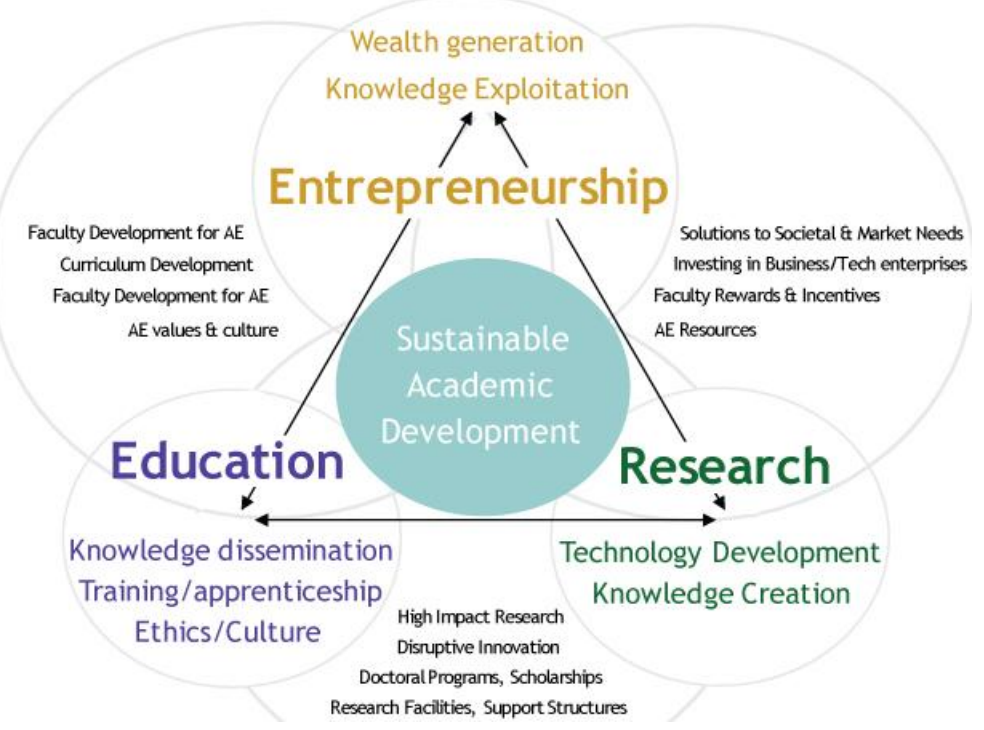

Figure 2. The Systematic Architecture of the Innovation Entrepreneurship Education

As shown above, we illustrate systematic architecture of the current innovation entrepreneurship education. Entrepreneurship orientation is entrepreneurship curriculum should follow the basic rules in the undergraduate course colleges and universities entrepreneurship curriculum should be located in the following three aspects. (1) Combining education mode for popularizing education and elite education. At first, entrepreneurship education is a universal enlightenment education for the students, cultivate the spirit of the pioneering consciousness and as the main purpose of the entrepreneurship education. The implementation of the entrepreneurship education to open mentality, form for all the student employment education idea. (2) Education purpose for the short-term employment combined with lifelong benefit. Entrepreneurship will try to meet the needs of college students employment recently, through the implementation of entrepreneurship education can make college students learn more about deep meaning of entrepreneurship curriculum, realize cultivate pioneering entrepreneurial talent's important role under the current employment situation. (3) Education content for the universal quality education combined with individual character difference education. In entrepreneurship curriculum implementation to effectively achieve primary entrepreneurship education as recognition and respect the differences. According to the professional differences and the individual differences, with the implement spirit $\mathrm{Wu}$ elastic entrepreneurship education [7].

The MOOCs. Stanford university president said a numbers of tsunami MOOC is the history of the education which is making its way through the traditional university. Real MOOC should have is characterized by the large, online education, online learning, open, free, mobile, excellent MOOC in addition to having the characteristics of open and free of general MOOC, should also have school, teacher, and these are their own hardware MOOC class influence.

Assessment and evaluation is, as it were, the MOOC is the most challenging problems in the credit approval. According to the above problem, the major MOOC platform and the university are taking measures to ensure the MOOC learning process and the authenticity and reliability of the examination results, ensure teaching quality and learning effect MOOC. The unique characteristics of the MOOC caused the MOOC learners the diversification of the purpose, background, and then led to participate in the 
path and the diversification of learning results, thus MOOC to obtain sustainable development, must pay attention to and meet the individualized needs of learners, support the diversification of the learner participation and learning. Accordingly, the study on MOOC can be organized as follows.

- Learning scientific research: MOOC provides scientific researchers in the field of learning as a new study situation, to extend their research in learning. At the same time, the MOOC support for the data automatic collecting and the randomized trials, allowing researchers and the core diversification of mass learners to interact.

- Human-computer interaction research: MOOC big data and uses the diversification of online learning resources as make the human-computer interaction research is very important. These studies include what types of interaction and internal process migration, the construction of the knowledge to promote learning.

- The characteristics of online learning research: MOOC gave rise to the use of technology to be effective, and how the new features of technical support and promote interaction research.

The Vocational Education in Colleges and Universities. Along with the social and economic development, vocational education in the realization of the system transition smoothly, the smooth transition of industry in our country, to realize our country from a big populous country to the human resources, the human resources in the fundamental shift of power to human resources power has an important strategic position. Vocational education management in vocational education to undertake strategic task has played a key role. With the deepening of reform of vocational education, education reform caused by the concept of innovation is bound to lead to the collision and the conflict of the inherent thought, in the game, vocational education stirs in the field of social precipitation caused all kinds of ideological trend of the ups and downs. Curriculum is the anchorage of vocational education and practice of soul is also a reformer and stick to the forefront of the game, course situation reflects the concept of vocational education and far-reaching influence on the relevant interest groups.

Under this condition, our future vocational education should following the listed guidelines. (1) Private higher vocational colleges in training high skilled society needs talents, so to take the initiative to adapt to the requirements of the popularization of higher education, adhere to the principle of the higher vocational education is given priority to, to adapt to the needs of economic take-off stage in our country. (2) Private colleges on the basis of the specific training target as should actively explore the laws and characteristics of the higher vocational education actively adjust their professional direction, set up a comprehensive, flexible application course, organize the implementation of practical teaching activities actively, and try to improve school conditions to really have its own characteristics. (3) The emphasis of higher vocational education courses with the professional set up pertinence, flexibility, management system more flexible private colleges, to have congenital advantage more than public colleges and the universities. Private higher vocational colleges should take full advantage of this advantage, target market, market shortage of professional to cultivate the market much-needed talent.

\section{Conclusion}

In this paper, we conduct research on the flip the classroom teaching mode for the modern innovation entrepreneurship classes under MOOCs background. Entrepreneurship education is the education for the students, should reflect the hierarchy, to deal with all the 
students and the relationship between entrepreneurial project team and the business elite oriented. To comprehensive reform of the existing classroom teaching, excavate the innovative education content of this major should be at the same time, the melt of the concept of entrepreneurship education. Strengthen entrepreneurship education and integration of professional teaching and inspire students to innovative entrepreneurship and the organic combination of major. Our research combines the analysis of MOOC and flips the classroom teaching mode to propose the novel optimized teaching methodology which is important.

\section{Acknowledgement}

This paper is financially supported by the project: Research on the flip the classroom teaching mode of innovation in entrepreneurship under the background of MOOCs.

\section{References}

[1] Simon, Beth. "Why the flip should I flip my classroom: results on the use of peer instruction in computing courses." Journal of Computing Sciences in Colleges 28.4 (2013): 92-92.

[2] Lucke, Terry, Ulrike Keyssner, and Peter Dunn. "The use of a classroom response system to more effectively flip the classroom." Frontiers in Education Conference, 2013 IEEE. IEEE, 2013.

[3] Smith, Jami S. "Active Learning Strategies in the Physician Assistant Classroom-the Critical Piece to a Successful Flipped Classroom." The Journal of Physician Assistant Education 25.2 (2014): 46-49.

[4] Boh, Wai Fong, Uzi De-Haan, and Robert Strom. "University technology transfer through entrepreneurship: faculty and students in spinoffs." The Journal of Technology Transfer (2012): 1-9.

[5] Harms, Rainer. "Self-regulated learning, team learning and project performance in entrepreneurship education: Learning in a lean startup environment." Technological forecasting and social change (2015).

[6] Cidon, Asaf, and Tomer London. "An interview with Peter Levine: academics as founders, teaching entrepreneurship." ACM Crossroads 18.4 (2012): 24-26.

[7] Rezaei, Jafar, Roland Ortt, and Victor Scholten. "Measuring entrepreneurship: Expert-based vs. data-based methodologies." Expert Systems with Applications 39.4 (2012): 4063-4074. 